\title{
GAMBARAN MINAT DAN PILIHAN KARIR ORANG SUNDA
}

\author{
Nani Nuranisah Djamal \\ Yulianti \\ Fakultas Psikologi UIN Sunan Gunung Djati Bandung, Jl. A.H Nasution No. 105 Bandung \\ email: bunda_ikmal@yahoo.co.id
}

\begin{abstract}
Abstrak
Berdasarkan data dilapangan, minat dan pilihan karir orang Sunda identik dengan pilihan karir yang kurang menantang. Hal tersebut tentunya berkaitan dengan kepribadian orang sunda yang dilandasi dengan nilai-nilai budaya lokal daerah sunda. Tujuan penelitian adalah melihat gambaran minat dan pilihan karir orang sunda dengan melakukan studi deskriptif kuantitatif terhadap 30 orang SMK di wilayah Bandung Timur. Hasil penelitian menunjukkan bahwa minat dan pilihan pekerjaan padea siswa yang berlatar belakang budaya sunda sebagian besar menunjukkan minat sosial yang cukup tinggi, kemudian enterprising dan konvensional.
\end{abstract}

Kata Kunci: Minat, karir, stereotipik, sunda

\section{Abstract}

Based on the data found, interest and career choices of sundanesse are commonly less challenging. It is related to sundanesse characteristic which is based on cultural values. The purposes of this research is obtaining interest description and career choice of sundanesse by having quantitative descriptive study of 30 SMK students in east Bandung as a sample. Result shows that interest and career choices from sunda cultural background mostly shows high social interest, enterprising and conventional.

Key words : interest, career, stereotype, sunda

\section{PENDAHULUAN}

Pembicaraan seputar minat dan pilihan karir, bukan sebatas wacana dalam program bimbingan konseling di lingkungan sekolah. Namun dalam tataran yang lebih luas lagi, pembicaraan tersebut dapat menjadi wacana pada level regional, nasional bahkan internasional. Terutama jika dikaitkan dengan budaya bangsa atau suku bangsa tertentu, akan menghasilkan penilaian stereotipik tentang minat dan pilihan karir setiap orang dengan suku bangsa yang berbeda. Sebagai contoh, orang batak yang memiliki karakter keras dan blak-blakan lebih identik dengan pilihan karir sebagai lawyer. Orang padang yang dikenal dengan julukan "pelit dan perhitungan" identik dengan pilihan karir sebagai pedagang. Benarkah pandangan hidup yang dimiliki oleh setiap suku bangsa berpengaruh terhadap minat dan pilihan karir masyarakatnya? Bagaimana halnya dengan orang sunda? Seperti apakah profil kepribadian kolektif yang dimiliki orang Sunda? Adakah keterkaitan antara kepribadian kolektif urang Sunda 
dengan dengan minat dan karir yang mereka pilih? Karir seperti apa yang dipilih oleh mayoritas orang Sunda? bagaimanakah gambaran minat dan pilihan karir orang Sunda? Faktor apa saja yang mempengaruhi minat dan pilihan karir orang Sunda? Penelitian ini dilakukan untuk menjawab pertanyaan-pertanyaan tersebut.

\section{Profil Kepribadian Kolektif Orang Sunda}

Dalam sebuah diskusi yang diselenggarakan di UPI Bandung, Rektor Unpad Prof. Dr. Gandjar Kurnia, DEA menyatakan pendapatnya sebagai berikut: "Terlalu jauh jika masyarakat Sunda menuntut menjadi Presiden Republik Indonesia. Pada kenyataannya, mereka belum memperlihatkan prestasi yang menonjol dalam memimpin wilayah sendiri.Gubernur Jabar orang Sunda, para bupati dan wali kota di Jabar umumnya juga orang Sunda. Tapi mengapa kita begini terus, Kondisi alam kita terus mengalami penurunan,"

Pendapat ini senada dengan MAW Brouwer seorang psikolog senior sekaligus tokoh yang merintis berdirinya Fakultas Psikologi UNPAD yang mengatakan bahwa ;

'Tuhan menciptakan tatar Parahyangan dalam keadaan tersenyum. Sebab, kawasan ini memang sangat indah dan subur. Namun, sayang, tatar Pasundan saat ini rusak parah. Hutan lindung di Jawa Barat hampir lenyap. Pada musim hujan, sebagian besar wilayah ini banjir. Sebaliknya, pada musim kemarau, mereka tak memiliki simpanan air. Sungai yang besar tercemar, sedangkan sungai kecil tak lagi berbekas".

Dalam paparannya bertema "Masyarakat Sunda dengan Alamnya", Gandjar mengemukakan, menuju masyarakat yang maju, adil, dan makmur harus didukung oleh lingkungan yang kondusif. Sementara itu, alam lingkungan di tatar Pasundan semakin tidak kondusif menciptakan situasi terbaik itu.

"Bisa jadi, kalau Albert Einstein lahir di tatar Pasundan, ia bukan jadi ahli fisika dan jadi pemikir hebat, melainkan sekadar jadi tukang bikin peuyeum (tape). Sebab, besar-kecilnya pemikiran seseorang sangat bergantung pada lingkungan sekitar yang menciptakannya," kata Gandjar.

Apa yang diungkapkan Rektor Unpad tersebut, di satu sisi menciutkan nyali urang Sunda dalam meniti karir. Tetapi di sisi lain itulah kenyataan yang harus diterima dengan lapang dada. Namun jangan sampai lupa, bahwa banyak urang Sunda yang "jeneng" di tingkat nasional. Banyak mutiara yang harus digali dalam jati diri masyarakat Sunda, diinventarisasi ulang, dan kemudian diformulasikan. Nilai yang bagus harus diperkokoh, sementara yang sudah ketinggalan zaman bisa disesuaikan, bahkan yang tidak relevan diganti.

Banyak nilai Sunda yang menunjuk pada kebijakan lokal (local wisdom). Hal itu ditandai dengan adanya kemampuan bertahan dari budaya luar, memiliki kemampuan mengakomodasikan unsur budaya luar, memiliki kemampuan mengintegrasikan unsur budaya luar ke dalam budaya asli, mempunyai kemampuan mengendalikan dan mampu memberi arah pada perkembangan budaya.

Dr Mikihiro Moriyama, guru besar tentang Indonesia Studies dari Nanzan University Jepang, mengungkapkan pandangan orang Belanda tentang masyarakat Sunda. Ia merujuk pada sebuah ensiklopedia (anonim) yang disusun orang Belanda awal abad ke-20 yang menyatakan, orang Sunda memiliki beberapa sifat yang dirasakan sangat menarik oleh banyak orang Eropa yang pernah tinggal bersama bangsa itu.

"Dia halus, sopan, suka menolong, ramah, dan menghindari pertengkaran dan perkelahian. Dia sederhana, tidak berlebihlebihan, tenang, pendiam, pemalu, sopan dalam pergaulan. Sudah barang tentu, ada 
pula sifat yang terselubung. Kesopanan dan sifatnya yang penurut sering menjadi sikap membudak dan mencari muka," kata Mihikiro Moriyama.

Masih menurut Moriyama, biasanya orang Sunda tidak mempunyai inisiatif, berhemat dianggap aneh baginya, seperti halnya menjunjung kebenaran. "Perjudian dan perbuatan asusila menimbulkan banyak korban di antara orang Sunda," ujar Mikihiro Moriyama.

\section{Gambaran umum mengenai minat dan pilihan karir urang Sunda}

Ada ungkapan yang menyebutkan bahwa tatar sunda dibuat ketika Tuhan tersenyum. Ini merupakan gambaran alangkah indah, aman dan nyamannya kondisi tempat tinggal alam parahiyangan ini. Hal ini mempengaruhi karakteristik orang sunda itu sendiri, sebagaimana hasil penelitian Moriyama yang menyebutkan bahwa karakteristik orang sunda yang khas dengan keramahtamahannya, sopan, pandai bergaul, sederhana dan disisi lain memunculkan sifat terselubung kurang inisiatif, boros dan pandai mencari muka. Berdasarkan karekteristik tersebut, maka memunculkan beragam pilihan karir bagi orang sunda yang mana fenomena saat ini dominasi minat karirnya memilih untuk memasuki pekerjaan, karier yang jelas dan aman seperti menjadi PNS, guru, karyawan BUMN, ataupun karyawan pabrik dan perusahaan swasta. Sebagaimana gambaran yang dilaporkan http://www.sabugacenter.com/fullpost/new s---events/1316233745/jobs-db--ribuan-

penganggur-serbu-career-expo-disabuga.html pada kegiatan Career Expo 2011 yang merupakan rangkaian dari JobsDB.com International Series, dihadiri oleh pengunjung sebanyak 2000 orang pada hari pertama Kegiatan Career tersebut. Antrian panjang tampak di stand PT Pertamina dan Indofood. Fenomena senada juga terlihat pada antrian lamaran CPNS dari tahun ke tahun di Jawa Barat yang diperebutkan oleh ribuan orang pelamar yang mayoritas penduduk Jawa Barat.

Fenomena minat karir menjadi karyawan dan pegawai di atas, berbanding terbalik dengan minat karir pada politik, sebagaimana paparan Ginandjar Kartasasmita (2011) di salahsatu Koran lokal Jawa Barat yang menyebutkan bahwa menjelang Pemilihan Umum (Pemilu) 2014, dipastikan tidak akan ada orang Sunda yang manggung di kancah politik nasional. Sebab, lanjutnya, tidak ada satu orang Sunda pun yang menduduki ketua partai maupun sekjen partai politik (parpol).Ginanjar menyatakan bahwa: "Saya pikir pemimpin dari orang Sunda telah habis, itu terlihat setelah masa jabatan saya di kabinet dan ketua dewan perwakilan daerah (DPD) tidak ada yang meneruskan sebagai top pimpinan di pusat,".

Ginanjar (2011) memaparkan bahwa masalah itu muncul karena kurang atau lemahnya pengkaderan oleh masyarakat Sunda terhadap parpol. Ia mengatakan, budaya mangga ti payun di kalangan masyarakat Sunda mempengaruhi minat karir pada orang sunda itu sendiri dan slogan ini harus diubah. "Ini dimunculkan, agar masyarakat Sunda bisa lebih leluasa dalam berpolitik maupun dalam bidang lainnya.Sudah saatnya orang Sunda makalangan (berkiprah) di pentas nasional. Apalagi Jawa Barat merupakan provinsi terbesar di Indonesia dengan suku terbesar kedua di Indonesia.

Selanjutnya, Ketua Badan Musyawarah Masyarakat Sunda (Bammus) Jabar, H. Memet H. Hamdan menyebutkan, bahwa "Tidak benar tidak ada masyarakat Sunda yang menjadi top pimpinan di pusat. Ia yakin ada, hanya mereka tidak terekspos atau tidak mau diekspos. Hal tersebut juga merupakan ciri khas orang Sunda yang dipengaruhi budayanya untuk tidak muncul di permukaan.

http://www.sabugacenter.com/fullpost/new s---events/1316233860/ginandjar-orang- 
sunda-tak-lagi-manggung.html. Padahal dari sejak masa kemerdekaan, karir politik gemilang orang sunda yang terukir sampai tingkat pemerintah RI banyak dicapai seperti Umar Wirahadikusumah yang pernah menjabat sebagai wakil presiden RI, Otto Iskandar Dinata (Jalak Harupat), Syafruddin prawinegara, Mohammad Toha, Ir. Juanda, Nana Stresna (Diplomat).

Minat karir suku sunda pada bidang bisnis/entrepreneurship juga jumlahnya hanya sedikit. Hasil wawancara pada mahasiswa sunda yang ditanyakan minat karir setelah selesai kuliah adalah ingin jadi guru atau pegawai atau karyawan saja. Jarang yang mengemukakan ingin menjadi entrepreneur. Profesi entrepreneur yang berani mengambil resiko ini tidak banyak terjiwai karena budaya yang ada pada suku sunda cukup kuat mempengaruhi kepribadiannya. Meskipun ada beberapa entrepreuneur yang sukses di bidang ini yaitu Arifin Panigoro, H Atang Ampera dan sebagainya.

Berbeda dengan minat karir entrepreneurship yang sedikit, minat suku sunda yang cukup menonjol ada pada karir seni budaya. Banyak tokoh sunda /inohong seperti kang kabayan (kang ibing alias Rd. Aat Surya), Kang Aom Kusman, Indrawati Lukman yang sudah melanglang buana mengelilingi Eropa, Amerika dan mang Udjo yang angklungnya sampai ke UNESCO.

Minat karir bidang akademik orang sunda diwakili Rektor UPI Sunaryo Kartadinata, Gandjar Kurnia rekor Unpad, RD. Ajeng Dewi Sartika, Muhamad Surya, Haji Hasan Mustopa. Sosial Keagamaan diwakili oleh KH.Miftah Farid, dan KH.Abdullah Gymnastiar.

Lain halnya dengan minat pada bidang hukum seperti menjadi pengacara, hakim dan jaksa, orang sunda juga jarang sekali yang memasuki karir ini meskipun ada beberapa yang berminat.

Dengan demikian, berdasarkan paparan diatas, sebenarnya orang sunda mempunyai ketertarikan karir pada berbagai bidang dari mulai politik, akademik, seni budaya, wirausaha, konvensional (pegawai) dan social budaya. Tetapi minat karir yang dominan ternyata ada pada bidang tertentu seperti pendidikan dan social budaya sedangkan minat karir yang sifatnya menantang dan butuh ketegasan seperti menjadi tentara, pengacara dan hakim jarang sekali. Hal tersebut memberi gambaran bahwa kondisi budaya dan filsafat dasar yang dijadikan pegangan orang sunda cukup mengakar pada diri orang sunda hingga mempengaruhi minat karir mereka.

Ada contoh orang sunda menarik untuk dikaji, sosok orang sunda yang berani keluar dari kebiasaan orang Sunda yang banyak memegang prinsip "bengkung ngariung bongkok ngaronyok" (selalu berkumpul bersama-sama dalam suka dan duka), namun tetap memegang teguh nilaii-nilai luhur budaya sunda. Ia sudah 46 tahun melanglang buana di kota New York Amerika, namanya mang Singgih. Mang Singgih bekerja sebagai tukang sapu sampai akhirnya mengumpulkan uang untuk membeli taksi dan menjadi pegawai bagi dirinya sendiri yaitu menjadi supir taksi. Dalam perjalanannya, mang Singgih tetap berpegang teguh pada kasundaan yang sudah terinternalisasi pada dirinya.

\section{Faktor-faktor yang mempengaruhi minat dan pilihan karir urang Sunda}

Budayawan Sunda Ajip Rosidi melontarkan kritik pedas soal mental dan perilaku orang Sunda. Kritik itu disampaikannya lewat orasi ilmiah saat menerima penganugerahan gelar Doktor Honoris Causa di bidang Ilmu Budaya pada Fakultas Sastra dari Universitas Padjadjaran. Ajip memulai pidatonya tentang kondisi orang Sunda yang jarang tampil di gelanggang nasional sejak lama, padahal jumlahnya secara kesukuan nomor dua diantara suku-suku bangsa yang membentuk Indonesia. Tidak ada orang Sunda yang menjadi presiden. Adapun yang menjadi Wakil Presiden hanya satu 
orang dan tidak menunjukkan prestasi yang membanggakan. "Mungkin karena merasa menjadi ban serep saja," katanya.

Orang Sunda yang menjadi pejabat negara dan duduk di parlemen pun jumlahnya sedikit. Selanjutnya Ajip merunut kiprah orang-orang Sunda sejak jaman pergerakan sebelum proklamasi kemerdekaan dan sesudahnya berdasarkan catatan sejarah. Kegelisahan tentang perasaan orang Sunda yang seakan-akan tidak dihargai dalam lingkungan nasional itu muncul hampir seabad lalu.

Ajip mengutip ucapan siswa STOVIA Dajat Hidajat pada 1913 saat menggagas Pagoejoeban Pasoendan yang terbentuk pada $1915 . \quad$ Dajat mempersoalkan sedikitnya orang Sunda yang menjadi siswa kedokteran dibanding suku Jawa dan Melayu. Ia pun menyinggung berbagai jabatan di Tanah Pasundan yang disandang suku lain.

"Keadaan orang Sunda di Tatar Sunda rasanya tak banyak bedanya, bahkan lebih menyedihkan," kata Ajip. Menurut dia, orang Sunda banyak yang suka menipu diri sendiri dengan jalan menutupi kenyataan dan kata-kata yang menyenangkan hati sendiri. Misalnya, orang Sunda itu berbudi halus, suka mengalah, dan selalu mendahulukan orang lain. Kenyataannya banyak orang Sunda yang mau melakukan apa saja demi kedudukan. "Artinya munafik, perkataan tidak sesuai dengan kata hati dan keinginannya," ujarnya.

Kemunafikan itu dianggap wajar akibat feodalisme yang masih tebal pengaruhnya dalam kehidupan orang Sunda. Pengaruh feodalisme Jawa setelah dijajah kerajaan Mataram pada 1624-1708, kata Ajip, melahirkan tingkatan (undak usuk) bahasa Sunda, serta takut menyatakan pendapat secara terus terang. Adapun akibat penjajahan Belanda, orang Sunda menjadi terbiasa mengabdi, memiliki mentalitas ingin terpakai oleh majikan atau atasan, dan tidak berani bersaing dengan orang lain.
Alam Sunda adalah alam pegunungan yang subur. Karena kesuburan alamnya ini, mayoritas masyarakat Sunda menyandarkan hidupnya pada usaha bertani di huma. Sebagai petani, mereka menggantungkan nasib sepenuhnya pada kebaikan alam yang memberikan hujan dan panas. Kesuburan alam dan ketergantungan ini, setelah berevolusi beratus-ratus tahun, membentuk suatu sikap mental dan prototipe khas masyarakat agraris yang cenderung pasif, malas, kurang inovatif, kurang kerja keras, kurang bervisi ke depan dan tidak berwawasan global karena alam telah menyediakan, memberikan dan memudahkan segalanya. Eksplanasi logika alam ini menjelaskan sejarah masyarakat Sunda sendiri.

\section{TINJAUAN TEORITIK}

\section{KONSEP MENGENAI MINAT DAN PILIHAN KARIR}

Banyak teori yang membahas mengenai minat dan pilihan karir dengan penekanan yang berbeda-beda. Yosh dan Corbishley (1987) menyebutkan, sedikitnya ada 7 teori yaitu: 1) teori trait factor dari League (1941) \& Williamson $(1939,1965), 2)$ Teori perkembangan (Ginzber dkk, 1951), 3) teori self-concept (Donald Super: 1957, 1969), 4) teori personality traits (Roe, 1956), 5) teori vocational identity (Tiedeman \& O'hara, 1963), 6) teori Holland dari John Holland (1985) yang dikenal sebagai teori personalities and work environment 7) Teori Krumboltz (Krumboltz dan Thoresen, 1969; Krumboltz, 1976).

Dari ketujuh teori tersebut, yang akan digunakan dalam menganalisis minat dan pilihan karir orang Sunda adalah teori Holland. Menurut Holland, kepribadian seseorang akan mempengaruhi pekerjaannya, sebaliknya pekerjaan juga akan dipengaruhi oleh kepribadian seseorang. Holland memprediksi bahwa apa yang disukai oleh seseorang, akan mengantarkan ia untuk memilih pekerjaan 
yang sesuai dan memungkinkan dia untuk memuaskan serta membuat orang tersebut berprestasi (Yosh dan Corbishley,1987). Secara singkat, teori Holland ini menunjukkan adanya hubungan timbal baik antara kepribadian dan lingkungan, sebagai faktor penentu minat dan pilihan karir seseorang.

Gibson dkk. (1995: 305) memaknai karir sebagai rangkaian sikap dan perilaku yang berkaitan dengan pengalaman dan aktivitas kerja selama rentang waktu kehidupan seseorang dan rangkaian aktivitas kerja yang terus berkelanjutan. Dengan demikian karir seorang individu melibatkan rangkaian pilihan dari berbagai macam kesempatan.

Sedangkan Greenhaus (1987: 5) seperti yang dikutip oleh Irianto (2001: 93) terdapat dua pendekatan untuk memahami makna karir, yaitu : pendekatan pertama memandang karir sebagai pemilikan ( $a$ property) dan/atau dari occupation atau organisasi. Pendekatan ini memandang bahwa karir sebagai jalur mobilitas di dalam organisasi yang tunggal seperti jalur karir di dalam fungsi marketing, yaitu menjadi sales representative, manajer produk, manajer marketing distrik, manajer marketing regional, dan wakil presiden divisional marketing dengan berbagai macam tugas dan fungsi pada setiap jabatan.Pendekatan kedua memandang karir sebagai suatu properti atau kualitas individual dan bukan occupation atau organisasi. Pendekatan ini memandang bahwa karir merupakan perubahanperubahan nilai, sikap, dan motivasi yang terjadi pada setiap individu.

Berdasarkan kedua pendekatan tersebut definisi karir adalah sebagai pola pengalaman berdasarkan pekerjaan (workrelated experiences) yang merentang sepanjang perjalanan pekerjaan yang dialami oleh setiap individu dan secara luas dapat dirinci ke dalam obyective events. Salah satu contoh untuk menjelaskannya melalui serangkaian posisi jabatan/pekerjaan, tugas atau kegiatan pekerjaan, dan keputusan yang berkaitan dengan pekerjaan (work-related decisions). Tidak hanya itu saja, juga mengenai interpretasi subyektif tentang peristiwa yang berkaitan dengan pekerjaan (workrelated events) baik pada masa lalu, kini dan mendatang seperti aspirasi pekerjaan, harapan, nilai, kebutuhan dan perasaan tentang pengalaman pekerjaan tertentu.

\section{FILOSOFI TES MINAT HOLLAND}

Tes Holland merupakan salah satu jenis alat diagnostic untuk mengetahui minat bakat seseorang. Alat tes ini dikembangkan oleh seorang konselor karir bernama John Lewis Holland. Ia lahir di Omaha, Nebraska, pada tanggal 21 Oktober tahun 1919. Holland mulai merancang alat tes pada tahun 1953, yang dikenal dengan the Vocational Preference Inventory (VPI). Ide ini berawal dari rasa penasaran dan ketidakpuasan Holland terhadap alat assessment yang banyak digunakan kala itu. Kemudian muncul pemikiran mengapa tidak menggunakan alat tes yang dapat mengukur beberapa jenis pekerjaan sekaligus, daripada hanya satu jenis pekerjaan? (http://aa.wrs.yahoo.com).

Tes minat Holland, terdiri dari empat bagian yang keseluruhannya dimaksudkan untuk memperoleh gambaran mengenai bidang minat seseorang berdasarkan tipologi Guilford. Menurut Holland tipologi ini merupakan yang paling bermanfaat sampai saat ini dibandingkan tipologi lainnya. Guilford membagi manusia dalam 6 bidang minat dan sifat kepribadian, yaitu: Mechanical, scientific, social welfare, clerical, business dan esthetic. Berdasarkan keenam bidang interest tersebut, Holland membuat analoginya menjadi enam tipe kepribadian dan enam tipe lingkungan yang dapat mempengaruhi bidang minat seseorang (Sumintardja, 2000) yaitu: tipe realistic, tipe investigative, Artistic, Social, 
Enterprising dan Conventional (dikodekan dengan huruf RIASEC).

Kode-kode ini (RIASEC) mewakili seperangkat tipe kepribadian yang dijelaskan dalam teori karir dan pilihan pekerjaan. Holland berpendapat bahwa "pilihan pekerjaan mengekspresikan kepribadian" dan bahwa enam faktor tipologi yang disusunnya, dapat digunakan untuk mendeskripsikan baik orang maupun lingkungan kerjanya. Tipologi Holland menyediakan struktur interpretatif untuk sejumlah minat pekerjaan yang berbeda, termasuk dua pengukuran yang ia kembangkan yaitu: The Vocational Preference Inventory (VPI) dan the Self Directed Search. Model ini telah diadopsi oleh Departemen Tenaga Kerja AS untuk mengkategorikan pekerjaan yang relatif sesuai dengan minat.

Teori Holland tidak mengasumsikan bahwa hanya ada satu tipe orang atau "hanya ada enam jenis orang di dunia." Sebaliknya, ia berasumsi bahwa setiap orang dapat digambarkan sebagai memiliki kepentingan terkait dengan masing-masing dari enam jenis dalam urutan preferensi. Asumsi ini memungkinkan Kode Holland dapat digunakan untuk menggambarkan 720 pola kepribadian yang berbeda. Meskipun pada prakteknya, klasifikasi pekerjaan hanya diambil dua atau tiga kode yang paling dominan yang biasa digunakan untuk keperluan bimbingan vokasional.( Winchester, 2010)

Dalam menyajikan teorinya, Holland merangkum keenam tipe tersebut dalam bentuk gambar hexagon. Gambar hexagon ini secara empiris menentukan hubungan antar tipe Semakin pendek jarak antara sudut pada segi enam tersebut, maka semakin dekat keterkaitannya. Teori hexagonal yaitu teori yang menunjukkan pentingnya lingkungan pekerjaan dan interaksi antara pekerjaan dengan kepribadian. Penelitian Holland menunjukkan bahwa kepribadian akan berkembang di dalam lingkungan pekerjaan yang cocok dengan kepribadian yang dimiliki individu. (American Psychologist,2008). Dibawah ini adalah deskripsi teori hexagonal Holland:

1. Tipe Realistik yang preferensinya pada aktivitas-aktivitas yang memerlukan manipulasi eksplisit, teratur, atau sistematik terhadap obyek-obyek, alatalat, mesin-mesin, dan binatangbinatang. Tidak menyukai aktivitasaktivitas pemberian bantuan atau pendidikan. Preferensi-preferensi membawa kepada pengembangan kompetensi-kompetensi dalam bekerja dengan benda-benda, binatangbinatang, alat-alat dan perlengkapan teknik, dan mengabaikan kompetensi sosial dan pendidikan. Menganggap diri baik dalam kemampuan mekanikal dan atletik dan tidak cakap dalam keterampilan-keterampilan sosial hubungan-hubungan insani. Menilai tinggi benda-benda nyata, seperti : uang dan kekuasaan. Ciri-ciri khususnya adalah praktikalitas, stabilitas, konformitas. Mungkin lebih menyukai keterampilan-keterampilan dan okupasiokupasi teknik.

2. Tipe Investigatif memiliki preferensi untuk aktivitas-aktivitas yang memerlukan penyelidikan observasional, simbolik, sistematik, dan kreatif terhadap fenomena fisik, biologis, dan kultural agar dapat memahami dan mengontrol fenomena tersebut, dan tidak menyukai aktivitasaktivitas persuasif, sosial, dan repetitif. Contoh-contoh dari okupasi-okupasi yang memenuhi kebutuhan-kebutuhan tipe-tipe investigatif adalah ahli kimia dan ahli fisika.

3. Tipe Artistik lebih menyukai aktivitasaktivitas yang ambiguous, bebas, dan tidak tersistematisasi untuk menciptakan produk-produk artistik, seperti lukisan, drama, karangan. Tidak menyukai aktivitas-aktivitas yang sistematik, teratur, dan rutin. Kompetensi-kompetensi dalam upaya- 
upaya artistik dikembangkan dan keterampilan-keterampilan yang rutin, sistematik, klerikal diabaikan. Memandang diri sebagai ekspresif, murni, independen, dan memiliki kemampuan-kemampuan artistik. Beberapa ciri khususnya adalah emosional, imaginatif, impulsif, dan murni. Okupasi-okupasi artistik biasanya adalah lukisan, karangan, akting, dan seni pahat.

4. Tipe Sosial, lebih menyukai aktivitasaktivitas yang melibatkan orang-orang lain dengan penekanan pada membantu, mengajar, atau menyediakan bantuan. Tidak menyukai aktivitas-aktivitas rutin dan sistematik yang melibatkan obyekobyek dan materi-materi. Kompetensikompetensi sosial cenderung dikembangkan, dan hal-hal yang bersifat manual \& teknik diabaikan. Menganggap diri kompeten dalam mcmbantu dan mengajar orang lain serta menilai tinggi aktivitas-attivitas hubungan-hubungan sosial. Beberapa ciri khususnya adalah kerja sama, bersahabat, persuasif, dan bijaksana. Okupasi-okupasi sosial mencakup pekerjaan-pekerjaan seperti mengajar, konseling, dan pekerjaan kesejahteraan sosial.

5. Tipe Enterprising, lebih menyukai aktivitas-aktivitas yang melibatkan manipulasi terhadap orang-orang lain untuk perolehan ekonomik atau tujuantujuan organisasi. Tidak menyukai aktivitas-aktivitas yang sistematik, abstrak, dan ilmiah. Kompetensikompetensi kepemimpinan, persuasif dan yang bersifat supervisi dikembangkan, dan yang ilmiah diabaikan. Memandang diri sebagai agresif, populer, percaya diri, dan memiliki kemampuan memimpin. Keberhasilan politik dan ekonomik dinilai tinggi. Ciri-ciri khasnya adalah ambisi, dominasi, optimisme, dan sosiabilitas.
6. Tipe Konvensional lebih menyukai aktivitas-aktivitas yang memerlukan manipulasi data yang eksplisit, teratur, dan sistematik guna memberikan kontribusi kepada tujuan-tujuan organisasi. Tidak menyukai aktivitasaktivitas yang tidak pasti, bebas dan tidak sistematik. Kompetensikompetensi dikembangkan dalam bidang-bidang klerikal, komputasional, dan sistem usaha. Aktivitas-aktivitas artistik dan semacamnya diabaikan. Memandang diri sebagai teratur, mudah menyesuaikan diri, dan memiliki keterampilan-keterampilan klerikal dan numerikal. Beberapa ciri khasnya adalah efisiensi, keteraturan, praktikalitas, dan kontrol diri. Okupasiokupasi yang sesuai adalah bankir, penaksir harga, ahli pajak, dan pemegang buku.

Teori original Holland mengalami modifikasi sebagai hasil dari penelitian ulang, hal ini terbatas pada lingkungan kerja pada masyarakat Amerika (Osipow, 1983 : 83). Holland juga berefleksi tentang jaringan hubungan antara tipe-tipe kepribadian dan antara model-model lingkungan,yang dituangkan dalam bagan yang disebut Hexagonal Model dan model ini menggambarkan aneka jarak psikologis antara tipe-tipe kepribadian dan modelmodel lingkungan (Winkel \& Hastuti, 2005 : 637). Menurut Holland suatu tipe memiliki korelasi dengan tipe-tipe lainnya, misalnya tipe realistik dekat dengan tipe investigatif di satu sisi dan dengan tipe konvensional di sisi lainnya (korelasinya 0,46 dan 0,36), sedangkan dengan tipe sosial korelasinya 0,21 (Osipow, 1983 : 83). Tipe artistik dekat hubungannya dengan tipe investigatif dan sosial (korelasinya 0,34 dan 0,42), tetapi jauh sekali dari tipe konvensional sehingga korelasinya 0,11 (Osipow, 1983 : 83). Keadaan tersebut tidak dapat disesuaikan secara tepat pada hexagon jika dimasukkan dalam ukuran skala, hal ini lebih merupakan sekedar suatu percobaan dari 
Holland untuk mempertalikan antara yang satu dengan yang lain (Osipow, 1983 : 90).

\section{FILOSOFI BUDAYA YANG MEMPENGARUHI PILIHAN KARIR ORANG SUNDA}

Pandangan hidup bagi orang Sunda adalah "konsep yang dimiliki seseorang atau golongan dalam suatu masyarakat yang bermaksud menanggapi dan menerangkan segala masalah hidup di dalam dunia ini". Pandangan hidup ini merupakan dasar bagi urang Sunda dalam menapaki kehidupan yang mereka jalani.

Pandangan hidup berkembang sebagai hasil interaksi antara faktor internal yang bersifat potensial pada diri manusia dengan faktor lingkungan yang merupakan hasil cipta, karsa dan karya manusia yang mewujudkan diri sebagai budaya. Budaya ini kemudian akan diinternalisasikan kepada setiap anggotanya melalui pendidikan dalam keluarga, adat-istiadat dan peran-peran social yang harus dimainkan oleh setiap individu yang menjadi anggota kebudayaan tersebut.

Sebelum kita menggali nilai-nilai filosofis orang sunda yang menjadi "ageman" (pegangan) dalam keseharian orang sunda dan berkembang menjadi nilai-nilai yang terinternalisasi kedalam pribadi orang sunda dalam berbagai aspek kehidupannya termasuk dalam bidang karir,maka alangkah baiknya jika kita mengenali dulu sebetulnya yang disebut orang sunda, kisunda atau kasundaan itu siapa. Beberapa tokoh sunda menjabarkan orang sunda itu adalah sebagai berikut:

Orang Sunda atau Ki Sunda menurut pendapat Saini KM (dalam Dangiang edisi 1/1999), bahwa: “...harus lebih dari hubungan intelektual, melainkan juga emosional dan bahkan intuituf yang sudah menjadi bagian kepribadiannya dan dengan demikian menentukan caranya berpikir dan bertindak. Tidak hanya memahami dan memiliki pengetahuan tentang kasundaan, tetapi menghayatinya dan melaksanakannya dalam kehidupan seharihari secara tidak sadar.

Pemaknaan lain tentang istilah orang Sunda (Urang Sunda), yang tertulis dalam Pandangan Hidup Orang Sunda (Suwarsih Warnaen et.al.1987:I) yaitu: "Orang Sunda adalah orang yang mengaku dirinya dan diakui oleh orang lain sebagai orang Sunda. Di dalam definisi tersebut tercakup kriteria berdasarkan keturunan (hubungan darah) dan berdasarkan sosial budaya sekaligus. Menurut kriteria pertama, seseorang atau sekelompok orang bisa disebut orang Sunda, jika orang tuanya, baik dari pihak ayah maupun dari pihak ibu atau keduanya orang Sunda, di mana pun ia atau mereka berada dan dibesarkan. Menurut kriteria kedua, orang Sunda adalah orang atau sekelompok orang yang dibesarkan dalam lingkungan sosial budaya Sunda dan dalam hidupnya menghayati serta mempergunakan normanorma dan nilai-nilai budaya Sunda. Dalam hal ini tempat tinggal, kehidupan sosial budaya dan sikap orangnya yang dianggap penting. Bisa saja seseorang atau sekelompok orang yang orang tuanya atau leluhurnya orang Sunda menjadi bukan orang Sunda karena ia atau mereka tidak mengenal, menghayati dan mempergunakan norma-norma dan nilainilai sosial budaya Sunda dalam hidupnya. Sebaliknya seseorang atau sekelompok orang yang orang tua atau leluhurnya bukan orang Sunda, menjadi orang Sunda karena ia atau mereka dilahirkan, dibesarkan dan hidup dalam lingkungan sosial budaya Sunda dalam hidupnya". ( Kebudayaan Sunda: 4).

Jadi yang disebut orang sunda sebagaimana paparan diatas adalah seseorang yang mempunyai keturunan sunda dan ada keterikatan dengan kasundaan karena memegang nilai-nilai dan budaya sunda yang dianut. Suryawilaga (2010) memaparkan kriteria orang sunda itu adalah sebagai berikuit:

1. Sunda Subyektif, yaitu bila seseorang berdasarkan pertimbangan subyektifnya 
merasa bahwa dirinya adalah Orang Sunda, maka dia adalah orang Sunda. Karena itu dia harus mengaktualisasikan dan mengaplikasikan Kasundaannya dalam berperilaku serta mempunyai konsep hidup yang NYUNDA.

2. Sunda Obyektif, yaitu bila seseorang dianggap oleh orang lain sebagai Urang Sunda, maka orang tersebut sepantasnya mampu mengaktulisasikan anggapan orang lain tsb. bahwa dirinya benarbenar Urang Sunda. Orang tersebut berkewajiban menunjukan Kasundaannya, yaitu dengan cara menunjukkan perilaku yang mencerminkan kasundaan.

3. Sunda Genetik, yaitu seseorang yang secara keturunan dari orang tuanya mempunyai silsilah Urang Sunda pituin (Orang Sunda asli). Malah dalam kebudayaan Sunda sering dirunut sampai pada generasi ketujuh di atas ego ( Tujuh turunan, yaitu indung/bapa - nini/aki, buyut, bao, janggawareng, udeg-udeg, kait/gantung siwur).

4. Sunda Sosio Kultural. Bila seseorang mempunyai ibu dan bapak atau salah satu di antaranya bukan Urang Sunda pituin (asli); tetapi walau pun demikian dalam kehidupan kesehariannya, baik dalam perilaku, adat-istiadat, berbahasa, berkesenian dan berkebudayaan, berfikir serta mempunyai konsep hidup seperti Urang Sunda.

Berdasarkan penjelasan diatas, maka pangertian tentang Urang Sunda tidak perlu berkonotasi rasis. Adapun yang terpenting dari setiap orang yang mengaku sebagai Urang Sunda adalah mempunyai komitmen teguh dalam mewujudkan kehidupan masyarakat Urang Sunda yang sejahtera lahir batin. Selamat dunia dan akhirat.

\section{STUDI LAPANGAN MENGENAI MINAT DAN PILIHAN KARIR ORANG SUNDA}

Pada bagian sebelumnya telah diuraikan mengenai keragaman karir yang dipilih oleh orang Sunda. Mulai dari pejabat tinggi negera, menteri, politisi, seniman, akademisi, pedagang, tukang sol hingga tukang kredit. Hal ini berarti, dalam lingkup mikro, pilihan karir orang Sunda itu cukup bervariasi. Namun dalam konteks makro, keunggulan-keunggulan itu kurang nampak. Tokoh-tokoh yang menasional yang berasal dari tanah Sunda dan dikenal oleh publik relative terbatas. Dalam lingkup nasional jarang ditemukan tokoh sunda yang menempati posisi top leader, namun di level middle cukup lumayan. Bahkan beberapa dari mereka menempati posisi penting dan strategis, namun keberadaan mereka jarang terekspose publik dan cenderung bekerja di belakang layar.

Fenomena di atas menimbulkan banyak pertanyaan seperti: apakakah kapasitas dan ability yang dimiliki orang sunda memang terbatas? Jika pertanyaan ini yang muncul nampaknya tidak tepat juga. Buktinya, banyak orang Sunda yang sukses dalam bidangnya masing-masing. Mungkinkah faktor budaya mempengaruhi tipikal kepribadian kolektif orang sunda? Untuk menjawab pertanyaan tersebut, perlu dilakukan pembuktian di lapangan. Oleh karena itu, kami melakukan studi lapangan Untuk memperoleh gambaran tentang minat dan pilihan karir orang Sunda.

Studi lapangan dilakukan terhadap siswa sekolah menengah yang berlatar belakang budaya Sunda. Dalam hal ini diwakili oleh salah satu SMK di wilayah Bandung Timur. Uraian mengenai studi lapangan tersebut adalah sebagai berikut:

$\begin{array}{lll}\begin{array}{l}\text { Tujuan studi : } \\ \text { lapangan }\end{array} & \begin{array}{l}\text { Untuk memperoleh } \\ \text { gambaran } \\ \text { mengenai minat } \\ \text { dan pilihan karir } \\ \text { orang sunda }\end{array} \\ \text { Sampel yang : } 30 \text { orang siswa }\end{array}$




$\begin{array}{ll}\text { terlibat } & \begin{array}{l}\text { (laki-laki=22, } \\ \text { perempuan=8) }\end{array} \\ \text { Daerah Asal }: \text { Garut, } & \text { Tasikmalaya, } \\ & \text { Cianjur, Bandung, } \\ \text { Instrumen } & \text { Tes minat bakat } \\ & \text { Holland yang } \\ & \text { terdiri dari 216 } \\ \text { pertanyaan. }\end{array}$

Pilihan minat karir siswa didasarkan pada tiga huruf pertama dalam tipologi Holland (yang jumlah seluruhnyan ada enam - RIASEC- ) Pemilihan tiga huruf pertama ini dimaksudkan untuk melihat dominasi atau kecenderungan minat yang dimiliki siswa.

Aspek yang ingin diungkap melalui studi lapangan ini adalah:

1. Memperoleh gambaran mengenai perbedaan kecenderungan minat siswa yang berlatar belakang budaya sunda secara umum.

2. Perbedaan kecenderungan minat antara siswa laki-laki sunda dengan siswa perempuan sunda

3. Variasi tipologi Holland pada kedua jenis subjek (laki \& perempuan)

4. Dominasi tipologi Holland pada masing-masing kelompok (laki \& perempuan)

5. Jenis pekerjaan yang dipilih Subjek

\section{HASIL DAN PEMBAHASAN}

TABULASI DATA HASIL SKORING TES HOLLAND

Tabel 1. Data Keseluruhan untuk 3 urutan pertama kode minat siswa

\begin{tabular}{|c|c|c|}
\hline Variasi Tipe & Jumlah & Prosentase \\
\hline A S C & 1 & $3,33 \%$ \\
\hline A S R & 1 & $3,33 \%$ \\
\hline A C E & 1 & $3,33 \%$ \\
\hline A S E & 3 & $10 \%$ \\
\hline C S E & 3 & $10 \%$ \\
\hline C S A & 1 & $3,33 \%$ \\
\hline C E R & 1 & $3,33 \%$ \\
\hline E S C & 2 & $6,67 \%$ \\
\hline E C S & 1 & $3,33 \%$ \\
\hline I S C & 1 & $3,33 \%$ \\
\hline I C A & 1 & $3,33 \%$ \\
\hline I S E & 1 & $3,33 \%$ \\
\hline R C S & 1 & $3,33 \%$ \\
\hline R S E & 1 & $3,33 \%$ \\
\hline
\end{tabular}

\begin{tabular}{|c|c|c|}
\hline S E C & 3 & $10 \%$ \\
\hline S C A & 2 & $6,67 \%$ \\
\hline S A I & 1 & $3,33 \%$ \\
\hline S A C & 2 & $6,67 \%$ \\
\hline S I E & 1 & $3,33 \%$ \\
\hline S E I & 1 & $3,33 \%$ \\
\hline S A E & 1 & $3,33 \%$ \\
\hline
\end{tabular}

\section{Deskripsi:}

Dari 30 orang siswa yang diukur, diperoleh 5 urutan tipologi yang sama, yaitu ASE CSE dan SEC(masing-masing 3 orang), ESC, SCA dan SAC (masingmasing 2 orang) selebihnya menunjukkan tipologi yang bervariasi. Berdasarkan data di atas, dapat ditarik kesimpulan bahwa setiap siswa menunjukkan minat yang berbeda-beda, hanya sebagian kecil saja yang memiliki minat yang sama. Hal ini membuktikan bahwa tes minat Holland cukup sensitive dalam mengukur perbedaan minat yang terdapat dalam diri setiap siswa.

\section{Tabel 2 Dominasi Tipologi Holland dari seluruh siswa}

Jumlah Siswa Laki-laki $=22$ orang, Perempuan $=8$ orang

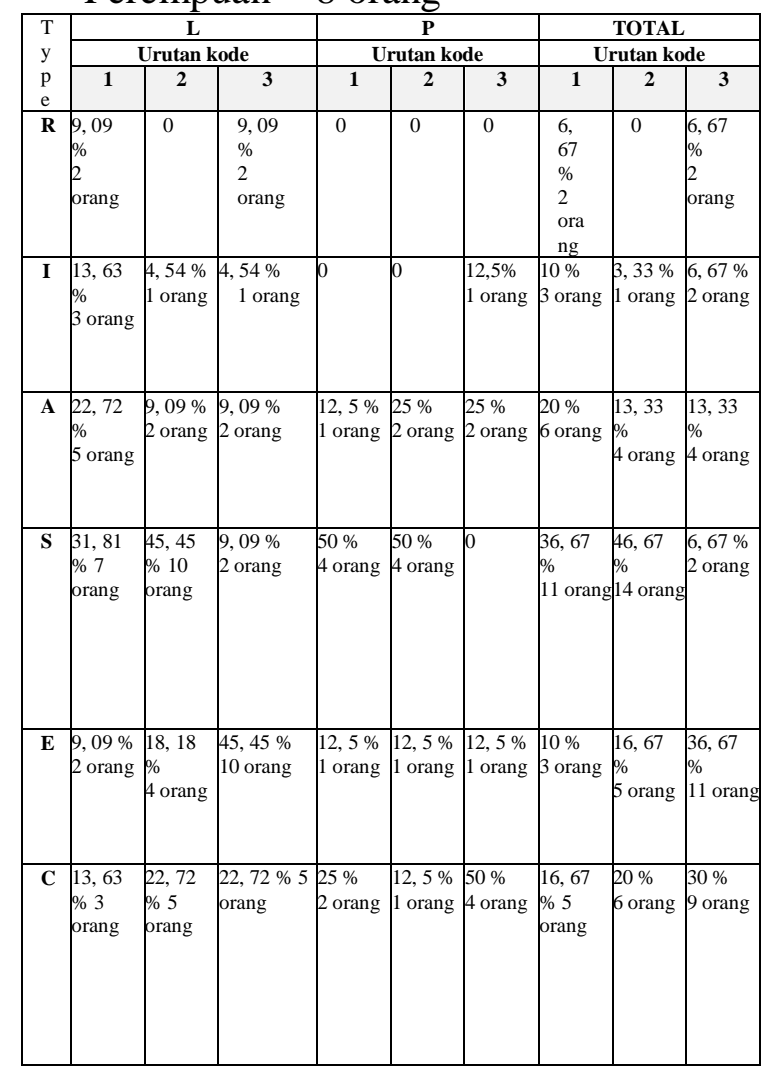


Dari data yang ditampilkan pada table 2, ada beberapa informasi yang dapat diperoleh yaitu:

1. Secara umum, siswa SMK $X$ yang berlatarbelakang etnik sunda, memiliki dominasi tipe social berdasarkan tipologi Holland, dengan urutan kode $\mathrm{S}$ pada pilihan pertama $(36,67 \%)$ dan urutan kedua (46\%). Jika dibedakan berdasarkan kelompok usia, maka kelompok perempuan lebih banyak bertipe social daripada kelompok siswa laki-laki.

2. Urutan tipe dominan berikutnya adalah tipe Enterpreneur (E) sebesar 36,7\%. Tipe entrepreneur lebih banyak dipilih oleh kelompok siswa laki-laki $(45,5 \%)$ daripada siswa perempuan $(11,67 \%)$ dengan posisi urutan ketiga.

3. Tipe Dominan terakhir adalah tipe Artistik (A) sebesar 20\%. Tipe artistiknya pada kelompok perempuan lebih dominan (25\%) daripada laki-laki $(22,72 \%)$.

4. Sedikit sekali siswa perempuan yang memiliki minat Investigasi (I) dan Realistik (R). Sedangkan pada kelompok laki-laki, masih ada yang berminat, namun tidak banyak $(\mathrm{I}=13,63 \%)$ dan $(\mathrm{R}=9,09 \%)$.

5. Pada kelompok perempuan yang paling dominan adalah minat terhadap social (S) dan Conventional (C)

6. Pada kelompok laki-laki yang paling dominan adalah Sosial (S), Artistik (A) dan investigatif (I),

\section{Tabel 3 Pilihan Pekerjaan siswa}

\begin{tabular}{|l|c|l|c|l|c|l|}
\hline \multirow{2}{*}{$\begin{array}{c}\text { Jenis } \\
\text { Pekerjaan }\end{array}$} & \multicolumn{2}{|c|}{ L } & \multicolumn{2}{c|}{ P } & \multicolumn{2}{c|}{ Total } \\
\cline { 2 - 5 } PumS & $\begin{array}{c}\text { Jumlah } \\
\text { orang }\end{array}$ & $\begin{array}{l}18,18 \\
\%\end{array}$ & $\begin{array}{c}1 \\
\text { orang }\end{array}$ & $\begin{array}{l}12,5 \\
\%\end{array}$ & 5 orang & $\begin{array}{l}16,67 \\
\%\end{array}$ \\
\hline Pengusaha & $\begin{array}{c}6 \\
\text { orang }\end{array}$ & $\begin{array}{l}27,27 \\
\%\end{array}$ & $\begin{array}{c}1 \\
\text { orang }\end{array}$ & $\begin{array}{l}12,5 \\
\%\end{array}$ & 7 orang & $\begin{array}{l}23,33 \\
\%\end{array}$ \\
\hline Atlet & $\begin{array}{c}1 \\
\text { orang }\end{array}$ & $\begin{array}{l}4,55 \\
\%\end{array}$ & - & - & 1 orang & $3,33 \%$ \\
\hline $\begin{array}{l}\text { Guru/Dos } \\
\text { en }\end{array}$ & $\begin{array}{c}8 \\
\text { orang }\end{array}$ & $\begin{array}{l}36,36 \\
\%\end{array}$ & $\begin{array}{c}3 \\
\text { orang }\end{array}$ & $\begin{array}{l}\% 7,5 \\
\%\end{array}$ & $\begin{array}{c}11 \\
\text { orang }\end{array}$ & $\begin{array}{l}36,67 \\
\%\end{array}$ \\
\hline Polisi/TNI & $\begin{array}{c}3 \\
\text { orang }\end{array}$ & $\begin{array}{l}13,63 \\
\%\end{array}$ & - & - & 3 orang & $10 \%$ \\
\hline Akuntan & - & - & $\begin{array}{c}2 \\
\text { orang }\end{array}$ & $25 \%$ & 2 orang & $6,67 \%$ \\
\hline Dokter & - & - & $\begin{array}{c}1 \\
\text { orang }\end{array}$ & $\begin{array}{l}12,5 \\
\%\end{array}$ & 1 orang & $3,33 \%$ \\
\hline Total & 22 & $100 \%$ & 8 & $100 \%$ & 30 & $100 \%$ \\
\hline
\end{tabular}

\begin{tabular}{|l|l|l|l|l|l|l|}
\hline & orang & & orang & & orang & \\
\hline
\end{tabular}

\section{Deskripsi:}

Tabel 3 menggambarkan pilihan citacita atau pekerjaan yang ingin ditekuni oleh siswa. Pilihan pekerjaan terbanyak adalah sebagai guru atau dosen $(36,67 \%)$ selanjutnya adalah pekerjaan sebagai pengusaha $(23,33 \%)$, urutan ketiga adalah pekerjaan sebagai PNS (16,67\%). Selebihnya sebagai polisi/TNI (10\%), sebagai akuntan $(6,67)$. Sedikit yang menginginkan jadi atlet dan dokter (masing-masing 3,3\%).

Minat untuk bekerja sebagai guru/dosen, cukup berimbang pada kelompok siswa laki-laki dan perempuan (36,36:37,5). Pada kelompok siswa perempuan tidak ada yang menginginkan pekerjaan sebagai polisi/TNI, sedangkan pada kelompok laki-laki tidak ada yang berminat menjadi akuntan maupun dokter. Padahal pada kelompok siswa perempuan, pekerjaan sebagai akuntan termasuk favorit. Minat untuk menjadi pengusaha lebih banyak pada kelompok laki-laki daripada perempuan

Secara umum, minat utama siswa SMK dengan latar belakang etnik sunda yang dijadikan sampel dalam studi lapangan, secara berurutan adalah adalah tipe Sosial (S). Ini berarti bahwa siswa dengan minat social ini, menandakan bahwa mereka lebih menyukai aktivitasaktivitas yang melibatkan orang-orang lain dengan penekanan pada membantu, mengajar, atau menyediakan bantuan. Tidak menyukai aktivitas-aktivitas rutin dan sistematik yang melibatkan obyekobyek dan materi-materi. Kompetensikompetensi sosial cenderung dikembangkan, dan hal-hal yang bersifat manual \& teknik diabaikan. Menganggap diri kompeten dalam membantu dan mengajar orang lain serta menilai tinggi aktivitas-attivitas hubungan-hubungan sosial. Beberapa ciri khususnya adalah kerja sama, bersahabat, persuasif, dan bijaksana. Dominasi tipe social ini 
diperkuat dengan pilihan pekerjaan yang diinginkan oleh sebagian besar siswa, yaitu sebagai guru.

Minat berikutnya adalah dalam bidang Enterprising (E), yaitu lebih menyukai aktivitas-aktivitas yang melibatkan manipulasi terhadap orangorang lain untuk perolehan ekonomik atau tujuan-tujuan organisasi. Tidak menyukai aktivitas-aktivitas yang sistematik, abstrak, dan ilmiah. Kompetensi-kompetensi kepemimpinan, persuasif dan yang bersifat supervisi dikembangkan, dan yang ilmiah diabaikan. Dominasi tipe enterprising ini juga menunjukkan adanya kesesuaian dengan pilihan pekerjaan sebagai pengusaha, yang juga cukup banyak diminati siswa.

Terakhir adalah minat dalam bidang

Konvensional (C). Dengan tipe ini, dimungkinkan para siswa lebih menyukai aktivitas-aktivitas yang memerlukan manipulasi data yang eksplisit, teratur, dan sistematik guna memberikan kontribusi kepada tujuan-tujuan organisasi. Biasanya menyukai keteraturan, mudah menyesuaikan diri, memiliki keterampilanketerampilan klerikal dan numerikal. Efisien praktis, terkontrol. Pilihan tipe ini cukup menggambarkan minat sebagian siswa dalam bidang akuntansi dan sebagai PNS.

Kecenderungan pilihan minat terfavorit pada kelompok siswa perempuan di luar guru/dosen adalah sebagai akuntan. Sedangkan minat yang favorit pada kelompok siswa laki-laki sunda adalah sebagai pengusaha.

Variasi tipologi Holland pada kedua jenis subjek (laki \& perempuan) cukup banyak dan cukup menggambarkan keragaman minat yang dimiliki siswa. Sedangkan dominasi pilihan minat ada pada urutan kode ASE, CSE, dan SEC. Jenis pekerjaan yang dipilih subjek, ternyata sesuai dan cukup menggambarkan pilihan minat pekerjaan mereka.

\section{KESIMPULAN}

Minat dan pilihan pekerjaan pada siswa yang berlatar belakang budaya sunda, sebagian besar menunjukkan minat sosial yang cukup tinggi. Hal ini membuktikan kesesuaian dengan tipikal kepribadian stereotipik orang sunda yang dikenal ramah, suka menolong orang, menyukai kebersamaan, menghindari konflik, kurang menyukai tantangan, dan cenderung memilih pekerjaan yang "aman" dan sudah jelas standar kerjanya.

$\checkmark$ Minat enterprising yang biasanya cenderung dihindari, justru menjadi alternatif kedua setelah minat sosial. Fenomena ini membuktikan bahwa orang sunda juga berani mengambil resiko. Tidak selalu mengekor pada orang lain.

$\checkmark$ Minat dalam bidang Convensional merupakan urutan ketiga. Dengan ciri menyukai rutinitas, pekerjaan yang sudah jelas aturan dan standarnya. Menyukai pekerjaan yang mendetail berbasis data seperti pekerjaan administratif.

Mengingat sampel yang terbatas dan metodologi yang sangat sederhana, maka kesimpulan ini berlaku dalam konteks yang terbatas pula.

$\checkmark$ Perlu dilakukan studi yang lebih mendalam dengan sampel yang lebih banyak dan lebih bervariasi, agar diperoleh data yang valid.

\section{DAFTAR PUSTAKA}

Bleeker, C. J. 1964. Pertemuan Agamaagama Dunia. Bandung: Sumur Bandung.

Chalil, Munawar. 1961. Kembali kepada Al-Qur'an dan Sunnah, Djakarta: Bulan Bin-tang.

Departemen Pendidikan dan Kebudayaan.1979). Sejarah Daerah Jawa Barat. Jakarta.

Rusyana, Yus. 1989. Pandangan Hidup Orang Sunda. Bandung: Departemen Pendidikan dan Kebudayaan. 
Suryani, Elis. 2008. Merumat Warisan Karuhun Orang Sunda. Alqa Prisma Interdelta. Jatinangor

Susanto, Phil Astrid S. 1999. Pengantar Sosiologi dan Perubahan Sosial. Jakarta. Putra A. Bardin

Warnaen, Suwarsih et.al. 1987. Pandangan Hidup Orang Sunda. Bandung: Bagian Proyek Penelitian dan Pengkajian Kebudayaan Sunda (Sundanologi) Depdikbud.

Yost, Corbishley. 1987. CAREER COUNSELING: A Psychological Approach . Jossey-Bass Inc., Publishers. USA.
Healy, Charles C. 1982. CAREER DEVELOPMENT: Counseling Through The Life Stages. Allyn Bacon, Inc. USA.

Suryani, NS. 2011. Ragam Budaya Sunda. Ghalia Indonesia.

Dik, Bryan J; Strife,Samatha Roberts; Hansen, Jo-Ida C. Career Development Quarterly, volume 58, number 4. June 2010.

http://konsultankarir.com/daftar-profesi/ http://singalodaya.wordpress.com http://img833.imageshack.us/img833/1015 hollandsimple.gif http://www.sundanet.com www.kasundaan.org 